\title{
Effects of Different Processing Treatments on Almond (Prunus dulcis) Bioactive Compounds, Antioxidant Activities, Fatty Acids, and Sensorial Characteristics
}

\author{
Ivo Oliveira ${ }^{1, *}$, Anne S. Meyer ${ }^{2}$, Sílvia Afonso ${ }^{1}$, Alex Sequeira ${ }^{3}$, Alice Vilela ${ }^{4}(\mathbb{D}$, \\ Piebiep Goufo ${ }^{1}{ }^{\mathbb{D}}$, Henrique Trindade ${ }^{1}$ and Berta Gonçalves ${ }^{1}$ \\ 1 Centre for the Research and Technology of Agro-Environmental and Biological Sciences-CITAB, \\ Universidade de Trás-os-Montes e Alto Douro (UTAD), Quinta de Prados, 5000-801 Vila Real, Portugal; \\ safonso@utad.pt (S.A.); pgoufo@utad.pt (P.G.); htrindad@utad.pt (H.T.); bertag@utad.pt (B.G.) \\ 2 Department of Biotechnology and Biomedicine, Technical University of Denmark, DTU Building 221, \\ DK-2800 Kgs, 2800 Lyngby, Denmark; asme@dtu.dk \\ 3 Universidade de Trás-os-Montes e Alto Douro (UTAD), Quinta de Prados, 5000-801 Vila Real, Portugal; \\ alexasequeira94@gmail.com \\ 4 Biology and Environment Department, CQ-VR, Chemistry Research Centre-Vila Real, Food and Wine \\ Sensory Lab, University of Trás-os-Montes and Alto Douro, 5001-801 Vila Real, Portugal; avimoura@utad.pt \\ * Correspondence: ivo.vaz.oliveira@utad.pt
}

Received: 26 October 2020; Accepted: 19 November 2020; Published: 23 November 2020

\begin{abstract}
Almond is one of the most commonly consumed nuts worldwide, with health benefits associated with availability of bioactive compounds and fatty acids. Almond is often eaten raw or after some processing steps. However, the latter can positively or negatively influence chemical and sensorial attributes of almonds. This work was carried out to assess the effects of two processing treatments, namely; roasting and blanching on (i) contents of bioactive compounds, (ii) contents of fatty acids (3) antioxidant activities (4), sensorial characteristics of four neglected Portuguese almond cultivars (Casanova, Molar, Pegarinhos and Refêgo) and two foreign cultivars (Ferragnès and Glorieta). Results showed that in general, levels of bioactive compounds and antioxidant activities increased with roasting and decreased with blanching. Fatty acid profiles of raw kernels of all cultivars were generally identical although Refêgo exhibited a high content of $\alpha$-linolenic acid. Following roasting and blanching, content of polyunsaturated fatty acids increased while saturated fatty acids, monounsaturated fatty acids and several health lipid indices decreased. Roasting positively affected perception of skin color and sweetness of Ferragnès and Glorieta as well as skin roughness of Molar and Pegarinhos. Blanching on the other hand led to positive changes in textural properties of Refêgo and Pegarinhos. This study reveals the nutritive benefits of consuming neglected almond cultivars in Portugal, and the novel data reported here could be of interest to growers, processing companies and consumers.
\end{abstract}

Keywords: Prunus dulcis; processing; sensorial analysis; fatty acids; antioxidant

\section{Introduction}

The consumption of nuts, including almonds, is associated with some positive health benefits such as antioxidant capacities, anticancer and antiatherogenic actions, as well as the regulation of immune and inflammatory responses [1]. The health benefits of almond are related to the availability of unsaturated fatty acids [2] and polyphenols which are known to improve human health [3]. Although almonds are mainly eaten in the raw state, sliced, or roasted, almonds can also be processed to obtain products such as marzipan, butter, milk, and oil [4]. Besides their direct consumption, almonds are 
added to several sweet or savory dishes and food products for special purposes, such as improve complexion or texture. Two major methods used in the processing of almonds are roasting and blanching [5]. Roasting and blanching can significantly alter the physical, chemical, and nutritive properties of the almond kernel, thus resulting in desired changes in texture, color, flavor, aroma, and taste [6]. Positive changes are particularly evident in the case of the brittle roasted almond, whose pleasant color and aroma results from the decrease in moisture level observed after roasting [7]. Modifications at a microstructural level due to processing can also lead to unwanted changes such as lipid oxidation and nutrient loss [8]. Almond processing can also result in unpleasant odor, flavor, and color [9] which influences sensorial acceptance by consumers [10]. The chemical composition of almonds is greatly influenced by pre-harvest factors such as geographical location, physiological events, cultural practices, harvesting plans (e.g., the maturity stage of the fruit at harvest) and genotype often regarded as the most important [11,12]. Thus, it can be hypothesized that the effect of processing on the composition of almond will vary based on the cultivars. In the north of Portugal, there is a large area of almond cultivation which has been assigned a Protected Designation of Origin (PDO) status: Amêndoa Douro. The cultivars grown in Amêndoa Douro have been the subject of few scientific studies [13-15]. Preliminary data indicate that these cultivars are low-yielding due to unsuitable soils and environments as well as poor management practices [13]. Currently, new orchards are being planted with foreign almond cultivars, including the French cultivar Ferragnès and the Spanish cultivar Glorieta [16]. Lack of knowledge about the nutritive value of Portuguese cultivars has led to the assumption that these cultivars are of low quality. As a result, most growers and processing companies have lost interest in the Portuguese cultivars. The overall goal of this study was to determine and compare raw, roasted, and blanched Portuguese (cultivars Casanova, Molar, Pegarinhos, and Refêgo) and foreign cultivars (Ferragnès and Glorieta) concerning their nutritive value (fatty acid composition), eating qualities (sensorial characteristics) and bioactivities (content of bioactive compounds and antioxidant activities).

\section{Results and Discussion}

\subsection{Content of Bioactive Compounds in Almond Cultivars}

Significant cultivar differences were observed in the total phenolic and total flavonoid contents of raw kernels (Table 1). The total phenolic content ranged from 0.048 in Glorieta to $0.189 \mathrm{mg}$ gallic acid equivalent (GAE)/g in Pegarinhos. The above range is similar to the range reported for other Portuguese cultivars (0.09-1.63 mg GAE/g; [17], but lower than the values reported for California (1.27-2.41 mg GAE/g; [18]) almonds. The values obtained for the total phenolic content in the present study are considerably different from the values obtained in our previous work using the same cultivars harvested in 2017 [14-16]. The above observation may be attributed to climate variability among the different growing seasons. Averagely, Portuguese cultivars had higher levels of phenolics $(0.10 \mathrm{mg} \mathrm{GAE} / \mathrm{g})$ than the foreign cultivars ( $0.06 \mathrm{mg} \mathrm{GAE} / \mathrm{g}$ in Ferragnès and $0.05 \mathrm{mg} \mathrm{GAE} / \mathrm{g}$ in Glorieta). The total flavonoid content ranged from 0.35 in Pegarinhos to $1.86 \mathrm{mg}$ catechin equivalents (CE)/g in Refêgo; the above values were considerably lower than those reported for the same cultivars harvested in previous years in Portugal [14]. Besides differences linked to the genotype, a strong influence of the harvest time is already known, suggesting that the synthesis of antioxidant compounds can occur in the last stage of ripening has already been reported. In the present work, all samples were harvested at commercial maturity, but slight variations on the ripening stage might be also linked to the differences between years.

\subsection{Effects of Roasting and Blanching on the Content of Bioactive Compounds in Almond}

Processing had a significant effect on the content of bioactive compounds in all almond cultivars (Table 1). Analysis of the results showed higher levels of phenolics in roasted kernels relative to raw kernels as observed in previous studies [19-21]. The above observation may be related to the potential increase in phenol extractability after the destruction of cellular structures in roasted kernels. In blanched almonds, the total phenolic content was generally reduced when compared to raw almonds 
although no significant effect was found for Casanova, Ferragnès, and Glorieta. Since blanched samples were also roasted, it may be assumed that the observed reductions in the total phenolic content in blanched kernels are due to skin removal. Indeed, $70-100 \%$ of almond phenolics is present in the skin [22] which is removed during blanching. Similarly, blanching led to reduced levels of flavonoids in the kernels. Accordingly, the total flavonoid content was similar for all cultivars after blanching but lower than contents in both raw and roasted samples. In general, roasting had no effect on the total flavonoid content of almond cultivars except for a $58 \%$ decrease for Molar and a $72 \%$ decrease for Refêgo. The above results are in contradiction to the increase in total phenolic content observed in all cultivars after roasting and might be an indication of the degradation of more complex phenolic structures such as polymerized proanthocyanidins and glycosylated flavonoids at high temperatures [19-21].

Table 1. Total phenolic content, total flavonoid content, and antioxidant activities of raw and processed almond kernels (mean f.w., $\mathrm{n}=3$ ).

\begin{tabular}{|c|c|c|c|c|c|}
\hline & Cultivar & Raw & Roasted & Blanched & $p$ Value \\
\hline \multirow{7}{*}{$\begin{array}{c}\text { Phenolics } \\
\text { (mg GAE/g FW) }\end{array}$} & Casanova & $0.09 \mathrm{~B} a, b$ & $0.49 \mathrm{~A} \mathrm{~b}$ & $0.04 \mathrm{~B} \mathrm{~b}$ & 0.001 \\
\hline & Ferragnès & $0.06 \mathrm{~B} \mathrm{~b}$ & $0.58 \mathrm{~A} \mathrm{~b}$ & $0.05 \mathrm{~B} a, b$ & 0.001 \\
\hline & Glorieta & $0.05 \mathrm{~B} \mathrm{~b}$ & $1.33 \mathrm{~A} \mathrm{a}, \mathrm{b}$ & $0.01 \mathrm{~B}$ c & 0.000 \\
\hline & Molar & $0.09 \mathrm{~B} a, b$ & $1.16 \mathrm{~A} \mathrm{a}, \mathrm{b}$ & $0.02 \mathrm{C} \mathrm{b,c}$ & 0.007 \\
\hline & Pegarinhos & $0.19 \mathrm{~B}$ a B & $0.88 \mathrm{~A} a, b$ & $0.08 \mathrm{C} \mathrm{a}$ & 0.003 \\
\hline & Refêgo & $0.02 \mathrm{~B} \mathrm{~b}$ & $2.66 \mathrm{~A} \mathrm{a}$ & $0.01 \mathrm{C} \mathrm{c}$ & 0.013 \\
\hline & $p$ value & 0.002 & 0.019 & 0.023 & \\
\hline \multirow{7}{*}{$\begin{array}{c}\text { Flavonoids } \\
(\mathrm{mg} \mathrm{CE} / \mathrm{g} \mathrm{FW})\end{array}$} & Casanova & $0.76 \mathrm{~A} \mathrm{~b}, \mathrm{c}$ & $1.23 \mathrm{~A} \mathrm{a}$ & 0.09B & 0.002 \\
\hline & Ferragnès & $0.59 \mathrm{~A} \mathrm{c}$ & $0.85 \mathrm{~A} a, b$ & $0.16 \mathrm{~B}$ & 0.033 \\
\hline & Glorieta & $0.77 \mathrm{~A} \mathrm{~b}, \mathrm{c}$ & $0.62 \mathrm{~A} \mathrm{a}, \mathrm{b}$ & $0.08 \mathrm{~B}$ & 0.020 \\
\hline & Molar & $1.38 \mathrm{~A} \mathrm{a}, \mathrm{b}$ & $0.58 \mathrm{~A} \mathrm{~b}$ & $0.06 \mathrm{C}$ & 0.000 \\
\hline & Pegarinhos & $0.35 \mathrm{~A} \mathrm{c}$ & $0.44 \mathrm{~A} \mathrm{~b}$ & $0.14 \mathrm{~B}$ & 0.000 \\
\hline & Refêgo & $1.86 \mathrm{~A} \mathrm{a}$ & $0.53 \mathrm{~A} \mathrm{~b}$ & $0.11 \mathrm{~B}$ & 0.001 \\
\hline & $p$ value & 0.000 & 0.014 & 0.578 & \\
\hline \multirow{7}{*}{$\begin{array}{c}\text { DPPH } \\
(\mu \mathrm{g} \text { Trolox/g) }\end{array}$} & Casanova & $4.02 \mathrm{~B} \mathrm{~b}$ & $9.48 \mathrm{~A} \mathrm{~b}$ & $0.48 \mathrm{C} a, b$ & 0.000 \\
\hline & Ferragnès & $2.82 \mathrm{~B} \mathrm{C}$ & $12.96 \mathrm{~A} \mathrm{a}$ & $0.42 \mathrm{C} \mathrm{b}$ & 0.001 \\
\hline & Glorieta & $1.54 \mathrm{~B} \mathrm{~d}$ & $4.86 \mathrm{~A} \mathrm{~b}$ & $0.70 \mathrm{C} \mathrm{a}$ & 0.016 \\
\hline & Molar & 3.37A b,c & $4.51 \mathrm{~A} \mathrm{~b}$ & $0.49 \mathrm{~B} a, b$ & 0.016 \\
\hline & Pegarinhos & $6.42 \mathrm{~A} \mathrm{a}$ & $7.60 \mathrm{~A} \mathrm{~b}$ & $0.64 \mathrm{~B} \mathrm{a}$ & 0.004 \\
\hline & Refêgo & $1.01 \mathrm{~A} \mathrm{~d}$ & $0.33 \mathrm{~B} \mathrm{c}$ & $0.01 \mathrm{C} \mathrm{c}$ & 0.000 \\
\hline & $\mathrm{p}$ value & 0.000 & 0.000 & 0.014 & \\
\hline \multirow{7}{*}{$\begin{array}{c}\text { ABTS } \\
(\mu \mathrm{g} \text { Trolox } / \mathrm{g})\end{array}$} & Casanova & $8.81 \mathrm{~B} a, b$ & $13.96 \mathrm{~A} \mathrm{a}$ & $0.47 \mathrm{C} \mathrm{b}$ & 0.000 \\
\hline & Ferragnès & $5.07 \mathrm{~B} \mathrm{c}, \mathrm{d}$ & $14.23 \mathrm{~A} \mathrm{a}$ & $0.56 \mathrm{C} a, b$ & 0.000 \\
\hline & Glorieta & $2.51 \mathrm{~B} \mathrm{~d}, \mathrm{e}$ & $8.92 \mathrm{~A} \mathrm{~b}$ & $0.44 \mathrm{C} \mathrm{b}$ & 0.000 \\
\hline & Molar & $7.27 \mathrm{~A} \mathrm{~b}, \mathrm{c}$ & $8.05 \mathrm{~A} \mathrm{~b}$ & $0.52 \mathrm{~B} a, \mathrm{~b}$ & 0.000 \\
\hline & Pegarinhos & $11.59 \mathrm{~A} \mathrm{a}$ & $11.14 \mathrm{~A} a, b$ & $0.68 \mathrm{~B} \mathrm{a}$ & 0.000 \\
\hline & Refêgo & $1.56 \mathrm{~A} \mathrm{e}$ & $2.64 \mathrm{~A} \mathrm{c}$ & $0.41 \mathrm{~B} \mathrm{~b}$ & 0.009 \\
\hline & $p$ value & 0.000 & 0.000 & 0.004 & \\
\hline \multirow{7}{*}{$\begin{array}{c}\text { B carotene } \\
\text { bleaching assay } \\
\text { (\% inhibition) }\end{array}$} & Casanova & $92.77 \mathrm{~A} \mathrm{a,b}$ & $78.50 \mathrm{~B}$ & $71.41 \mathrm{C}$ & 0.000 \\
\hline & Ferragnès & $95.85 \mathrm{~A} \mathrm{a}, \mathrm{b}$ & $78.25 B$ & $70.79 \mathrm{C}$ & 0.000 \\
\hline & Glorieta & $96.22 \mathrm{~A} \mathrm{a}$ & $80.65 \mathrm{~B}$ & $67.16 \mathrm{C}$ & 0.000 \\
\hline & Molar & $88.60 \mathrm{~A} \mathrm{~b}, \mathrm{c}$ & $76.08 \mathrm{~B}$ & $69.75 \mathrm{C}$ & 0.005 \\
\hline & Pegarinhos & $84.89 \mathrm{~A} 6 \mathrm{c}$ & 71.33B & $62.265 \mathrm{C}$ & 0.000 \\
\hline & Refêgo & $89.62 \mathrm{~A} \mathrm{~b}, \mathrm{c}$ & $80.77 \mathrm{~A}$ & 67.91B & 0.005 \\
\hline & $p$ value & 0.001 & 0.119 & 0.157 & \\
\hline
\end{tabular}

Different small letters in front of mean within a column indicate significant differences among cultivars for the same treatment. Different capital letters in front of mean within a row indicate significant differences among treatments for the same cultivar $(p<0.05$, ANOVA Tukey's test). 


\subsection{Antioxidant Activities of Almond Raw Extracts}

The antioxidant potential of the six almond cultivars was evaluated using three different methods (ABTS, DPPH and $\beta$-carotene) which enabled elucidation of the mechanism of action. Raw extract data presented in Table 1 show that highest ABTS and DPPH activities were obtained with Pegarinhos, followed by Casanova. The highest percentage inhibition of lipid peroxidation ( $\beta$-carotene-linoleic acid bleaching assay) on the other hand was obtained with Glorieta, Casanova and Ferragnès. Overall, the lowest antioxidant activities were recorded in Refêgo.

No correlations were found between the total flavonoid content and antioxidant activities. Nevertheless, positive correlations were found between the total phenolic content and ABTS $\left(R^{2}=0.7057\right.$, $y=50.67 x+1.7828)$ and between the total phenolic content and DPPH $\left(R^{2}=0.7892, y=0.0298 x\right.$ $-0.0093)$. Such correlations have already been reported in previous works using the same almond cultivars [14-16] (and in studies using walnut [23].

\subsection{Effects of Roasting and Blanching on the Antioxidant Activities of Almond Extracts}

Even if not significant, the average DPPH and ABTS activities of all the extracts increased after roasting except for the DPPH for Refêgo which was reduced by $67 \%$. As shown in Table 1, Ferragnès had the highest antioxidant activities after roasting followed by Casanova and Pegarinhos. Refêgo on the other hand exhibited the lowest activities. Additionally, Refêgo exhibited the lowest antioxidant activities after blanching. Blanching in general led to huge drops in DPPH and ABTS activities for all almond extracts. Indeed, the highest mean DPPH activity of $0.70 \mu \mathrm{g}$ Trolox/g observed for Glorieta (statistically similar to Casanova, Molar, and Pegarinhos) blanched kernels was two times lower than that of the raw kernels; the highest mean ABTS activity of $0.68 \mu \mathrm{g}$ Trolox/g observed for Pegarinhos (statistically similar to Ferragnès and Molar) blanched kernels was 17 times lower than that of the raw kernels. Results of the $\beta$-carotene-linoleic acid assay showed that roasting reduced the potential of almond samples to inhibit lipid peroxidation. The ability for almond to inhibit peroxidation was further reduced after blanching (Table 1).

Correlation analyses using data from roasted samples showed that ABTS $\left(R^{2}=0.708, y=-3.76362 x\right.$ $+14.27525)$ and DPPH $\left(R^{2}=0.545, y=-2.48231 x+16.18607\right)$ negatively correlated with the total phenolic content, a finding inconsistent with what was observed for raw samples. There were no significant correlations found with data from blanched samples. Negative correlations between phenolic levels and antioxidant activities were reported in few studies [24,25] linked these negative correlations to the unspecific nature of the Folin-Ciocalteu assay since the reagent targets all compounds with phenolic units with no consideration for the number of hydroxyl groups in a compound [26] or interfering compounds [27]. In the present study, negative correlations were likely due to different magnitudes of change due to roasting. For example, the $11000 \%$ increase in the total phenolic content of Refêgo after roasting was accompanied by only a $69 \%$ increase in the ABTS activity.

\subsection{Fatty Acid Composition of Almond Cultivars}

A total of 23 fatty acids were identified in the six almond cultivars. This number is similar to what was previously reported by Oliveira et al. (2019) [15] and Beyhan et al. (2011) [11]. Lower number of fatty acids in almonds have been reported in several studies [28,29]. These differences can be attributed mainly to genotype [30]. In the present study, 13 fatty acids exhibited high abundance and/or significant changes due to processing as shown in Table 2. In raw kernels, the most abundant fatty acid was C18:1 (elaidic + oleic acids), followed by C18:2 (linoleic + linolelaidic acids) except for Refêgo which had $\alpha$-linolenic acid as the second abundant fatty acid. Other major fatty acids were $\alpha$-linolenic and palmitic acids (Table 2). Most studies have reported oleic, linoleic, palmitic, and stearic acids $[15,28,31-34]$ as the most abundant fatty acids in almond. The content of $\alpha$-linolenic acid in almond is usually reported to be around $1 \%$. Thus, the $16.21 \%$ of $\alpha$-linolenic acid found in the present study for Refêgo can be considered high even when compared to the $11.00 \%$ and $9.45 \%$ reported by Askin et al. 
(2007) [35] and Oliveira et al. (2019) [15], respectively. This finding is extremely relevant given the important role that $\alpha$-linolenic acid plays in the reduction of diabetes and coronary heart diseases [36]. $\alpha$-linolenic acid is also the precursor of long-chain polyunsaturated fatty acids in the human body (e.g., eicosapentaenoic and docosahexaenoic acids) which have positive impacts on prothrombotic risk factors [37]. However, oils rich in linoleic and linolenic acids have reduced oxidative stability and hence are more prone to rancidity; this consequently results in the production of undesirable volatile compounds and off-flavors [38]. Oils rich in oleic acid on the other hand have better resistance to oxidation, longer shelf life and higher nutritional values [39]. Differences in the fatty acid composition of the six almond cultivars can be related to several factors such as the genotype and growing temperature which are the most important $[11,40]$.

\subsection{Effects of Roasting and Blanching on the Fatty Acid Composition of Almonds}

Although not always the case, both processing treatments (roasting and blanching) had similar effects on the fatty acid profile of almonds; however, the effect of blanching was stronger than that of roasting. After roasting, the major fatty acid in all cultivars remained C18:1 (elaidic + oleic acids). However, the second most abundant fatty acid in raw kernels (C18:2) was substituted in roasted kernels with $\alpha$-linolenic acid. Indeed, there was a sharp increase in the level of $\alpha$-linolenic acid in all cultivars after roasting except for Refêgo. Other major fatty acids identified in roasted kernels were erucic acid (third most abundant fatty acid in Casanova, Glorieta, and Pegarinhos), nervonic acid (third most abundant fatty acid in Ferragnès) and palmitic acid (second most abundant fatty acid in Refêgo and third in Molar). C18:1 (elaidic + oleic acids) and $\alpha$-linolenic acid were also the most abundant fatty acids after blanching except for Molar which had erucic acid as the second most abundant compound. Other fatty acids found in high contents after blanching were palmitic acid (third major fatty acid in Casanova), erucic acid (second major fatty acid in Molar and third in Ferragnès, Pegarinhos, and Refêgo) and nervonic acid (third major fatty acid in Molar).

Both roasting and blanching led to decreases in the contents of C18:1 (elaidic + oleic acids) and C18:2 (linoleic + linolelaidic acids) with the exception of Refêgo where an increase in the content of C18:1 was found after roasting. In fact, C18:2 (linoleic + linolelaidic acids) was undetectable in Ferragnès after roasting. Several studies $[6,37,41,42]$ have identified both increases and decreases in C18:1 levels after subjecting almonds to different processing treatments, although the changes observed in these studies were much lower in magnitude than those found in the present study. The content of palmitic acid generally decreased in almond samples after roasting and blanching (except for an increase for Molar and Refêgo after roasting and no change for Casanova, Glorieta and Molar after blanching). Research shows that roasting lead to increased levels of palmitic acid in almond [6,43]; the effect however, depends on the roasting temperature and time. In fact, the content of palmitic acid can be gradually reduced with prolonged exposure of kernels to high temperatures [41]. The content of stearic acid in almonds tended to decrease after roasting (except for an increase for Pegarinhos and Refêgo) and to increase after blanching (except for a decrease for Casanova and Refêgo). 
Table 2. Contents of the main (most abundant and/or most affected) fatty acids in almond oil extracted from raw, roasted, and blanched kernels $(\%$, mean, $\mathrm{n}=3$ ). Different small letters in front of mean within a row indicate significant differences among cultivars for the same treatment. Different capital letters in front of mean within a row indicate significant differences among treatments for the same cultivar $(p<0.05$, ANOVA Tukey's test). n.d.-not detected.

\begin{tabular}{|c|c|c|c|c|c|c|c|c|c|c|c|c|c|c|c|c|c|c|}
\hline \multirow[t]{2}{*}{ Cultivar } & \multicolumn{3}{|c|}{ Casanova } & \multicolumn{3}{|c|}{ Ferragnès } & \multicolumn{3}{|c|}{ Glorieta } & \multicolumn{3}{|c|}{ Molar } & \multicolumn{3}{|c|}{ Pegarinhos } & \multicolumn{3}{|c|}{ Refêgo } \\
\hline & Raw & Roasted & Blanched & Raw & Roasted & Blanched & Raw & Roasted & Blanched & Raw & Roasted & Blanched & Raw & Roasted & Blanched & Raw & Roasted & Blanched \\
\hline Palmitic & $6.94 \mathrm{~A} \mathrm{a}$ & $2.32 \mathrm{~B} \mathrm{C}$ & $6.27 \mathrm{~A} \mathrm{a}$ & $3.93 \mathrm{~A} \mathrm{c}$ & $3.02 \mathrm{AB} \mathrm{C}$ & $2.71 \mathrm{~B} \mathrm{c}$ & $2.92 \mathrm{c}$ & $2.52 \mathrm{c}$ & $2.96 \mathrm{c}$ & $2.63 \mathrm{~B} \mathrm{C}$ & $4.95 \mathrm{~A} \mathrm{~b}$ & $2.79 \mathrm{~B} \mathrm{C}$ & $6.54 \mathrm{~A} \mathrm{ab}$ & $2.14 \mathrm{C} \mathrm{c}$ & $3.57 \mathrm{~B} \mathrm{bc}$ & $5.45 \mathrm{~B} \mathrm{~b}$ & $7.10 \mathrm{~A} \mathrm{a}$ & $4.04 \mathrm{Cb}$ \\
\hline Stearic & $0.132 \mathrm{~A} a$ & n.d. & $0.071 \mathrm{~B} \mathrm{bc}$ & n.d. & n.d. & $0.36 \mathrm{a}$ & $0.13 a$ & n.d. & $0.259 \mathrm{ab}$ & $0.03 \mathrm{~B} \mathrm{C}$ & n.d. & $0.33 \mathrm{~A} \mathrm{a}$ & $0.11 \mathrm{Cb}$ & $0.17 \mathrm{~B} \mathrm{a}$ & $0.23 \mathrm{~A} \mathrm{ab}$ & n.d. & $0.09 \mathrm{~b}$ & n.d. \\
\hline Elaidic + Oleic & $70.02 \mathrm{~A} \mathrm{ab}$ & $34.05 \mathrm{~B} \mathrm{~d}$ & $68.26 \mathrm{~A} \mathrm{a}$ & $61.51 \mathrm{Ac}$ & $48.28 \mathrm{~B} \mathrm{~b}$ & $45.97 \mathrm{~B} \mathrm{c}$ & $77.03 \mathrm{~A} \mathrm{a}$ & $40.86 \mathrm{C} \mathrm{c}$ & $54.11 \mathrm{~B} \mathrm{~b}$ & $65.08 \mathrm{~A} \mathrm{bc}$ & $50.06 \mathrm{~B} \mathrm{~b}$ & $40.64 \mathrm{C} \mathrm{d}$ & $65.90 \mathrm{~A} \mathrm{bc}$ & $26.87 \mathrm{C} \mathrm{e}$ & $42.67 \mathrm{~B} \mathrm{~cd}$ & $66.07 \mathrm{~B} \mathrm{bc}$ & $82.19 \mathrm{~A} a$ & $52.17 \mathrm{Cb}$ \\
\hline $\begin{array}{c}\text { Linoleic + } \\
\text { Linolelaidic } \\
\end{array}$ & $13.54 \mathrm{~A} a b$ & $3.04 \mathrm{~B} \mathrm{~b}$ & $0.15 \mathrm{C} \mathrm{e}$ & $8.89 \mathrm{~A} \mathrm{~b}$ & n.d. & $1.05 \mathrm{~B} \mathrm{a}$ & $10.34 \mathrm{~B} \mathrm{ab}$ & $2.86 \mathrm{C} \mathrm{b}$ & $0.84 \mathrm{~A} \mathrm{~b}$ & $13.09 \mathrm{~A}$ ab & $0.36 \mathrm{~B} \mathrm{c}$ & $0.54 \mathrm{~B} \mathrm{~cd}$ & $14.18 \mathrm{~A} \mathrm{a}$ & 3.53B a & $0.41 \mathrm{Cd}$ & $1.08 \mathrm{~A} \mathrm{c}$ & $0.26 \mathrm{Cc}$ & $0.59 \mathrm{~B} \mathrm{c}$ \\
\hline$\gamma$-Linolenic & $0.17 \mathrm{~B}$ & $0.52 \mathrm{~A} \mathrm{~b}$ & n.d. & $0.104 \mathrm{~B}$ & $0.52 \mathrm{~B} \mathrm{~b}$ & $3.31 \mathrm{~A} \mathrm{a}$ & $0.096 \mathrm{C}$ & $0.75 \mathrm{~B} \mathrm{a}$ & $2.31 \mathrm{~A} \mathrm{~b}$ & $0.08 \mathrm{C}$ & $0.88 \mathrm{~B} \mathrm{a}$ & $2.32 \mathrm{~A} \mathrm{~b}$ & $0.12 \mathrm{C}$ & $0.48 \mathrm{~B} \mathrm{~b}$ & $1.66 \mathrm{~A} \mathrm{c}$ & n.d. & n.d. & $0.943 \mathrm{~d}$ \\
\hline$\alpha$-Linolenic & $4.14 \mathrm{C} \mathrm{cd}$ & $33.89 \mathrm{~A} \mathrm{~b}$ & $18.89 \mathrm{~B} \mathrm{~b}$ & $4.99 \mathrm{C} \mathrm{bc}$ & $33.54 \mathrm{~A} \mathrm{~b}$ & $9.94 \mathrm{~B} \mathrm{c}$ & $4.72 \mathrm{~B} \mathrm{bc}$ & $32.73 \mathrm{~A} \mathrm{~b}$ & $6.18 \mathrm{~B} \mathrm{~cd}$ & $1.92 \mathrm{~B} \mathrm{~d}$ & $30.59 \mathrm{~A} \mathrm{~b}$ & $2.48 \mathrm{~B} \mathrm{~d}$ & $6.74 \mathrm{Cb}$ & $46.97 \mathrm{~A} a$ & $23.85 \mathrm{~B}$ a & $16.21 \mathrm{~A}$ a & $4.77 \mathrm{~B} \mathrm{c}$ & $6.10 \mathrm{~B} \mathrm{~cd}$ \\
\hline $\begin{array}{c}\text { cis-11,14- } \\
\text { Eicosadienoic }\end{array}$ & n.d. & $0.33 \mathrm{~b}$ & n.d. & n.d. & n.d. & $1.39 a$ & n.d. & $0.49 \mathrm{~B} \mathrm{a}$ & $0.67 \mathrm{~A} \mathrm{~b}$ & n.d. & n.d. & $0.97 \mathrm{~b}$ & n.d. & $0.40 \mathrm{~B}$ ab & $0.67 \mathrm{~A} \mathrm{~b}$ & n.d. & n.d. & $0.69 \mathrm{~b}$ \\
\hline $\begin{array}{c}\text { cis-8,11,14- } \\
\text { Eicosatrienoic }\end{array}$ & d. & n.d. & $0.10 \mathrm{e}$ & n.d. & n.d. & $0.64 \mathrm{c}$ & n.d. & n.d. & $1.42 \mathrm{a}$ & n.d. & $0.27 \mathrm{~B} \mathrm{~b}$ & $0.83 \mathrm{Ab}$ & n.d. & $0.58 \mathrm{~A} \mathrm{a}$ & $0.37 \mathrm{~B} \mathrm{~d}$ & n.d. & n.d. & $0.32 \mathrm{~d}$ \\
\hline $\begin{array}{l}\text { cis-5,8,11,14,17- } \\
\text { Eicosapentaenoic }\end{array}$ & n.d. & n.d. & $0.10 \mathrm{~d}$ & n.d. & n.d. & $0.35 \mathrm{c}$ & n.d. & n.d. & $0.79 a$ & n.d. & $0.29 \mathrm{~B} \mathrm{~b}$ & $0.62 \mathrm{~A} \mathrm{ab}$ & n.d. & $0.48 a$ & $0.42 \mathrm{bc}$ & n.d. & n.d. & $0.30 \mathrm{~cd}$ \\
\hline Erucic & $1.97 \mathrm{~B} \mathrm{ab}$ & $5.64 \mathrm{~A} \mathrm{a}$ & $2.25 \mathrm{~B} \mathrm{~d}$ & $2.72 \mathrm{~B} \mathrm{a}$ & $3.62 \mathrm{~B} \mathrm{~b}$ & $7.34 \mathrm{Ab}$ & $0.98 \mathrm{~B} \mathrm{~cd}$ & $5.73 \mathrm{~A} \mathrm{a}$ & $5.73 \mathrm{~A} \mathrm{c}$ & $0.51 \mathrm{C} \mathrm{d}$ & $3.44 \mathrm{~B} \mathrm{~b}$ & $9.35 \mathrm{~A}$ a & $1.41 \mathrm{C} \mathrm{bc}$ & $4.29 \mathrm{~B} a \mathrm{~b}$ & $5.81 \mathrm{Cc}$ & $2.47 \mathrm{~B} \mathrm{a}$ & $2.59 \mathrm{~B} \mathrm{~b}$ & $6.32 \mathrm{~A} \mathrm{bc}$ \\
\hline Nervonic & $0.71 \mathrm{~B} \mathrm{~d}$ & $5.58 \mathrm{~A} \mathrm{a}$ & $0.73 \mathrm{~B} \mathrm{c}$ & $4.26 \mathrm{~A}$ a & $4.77 \mathrm{~A} \mathrm{ab}$ & $3.31 \mathrm{Cb}$ & $1.06 \mathrm{C} \mathrm{c}$ & $4.18 \mathrm{~B} \mathrm{bc}$ & $6.22 \mathrm{~A} \mathrm{a}$ & $0.47 \mathrm{C} \mathrm{d}$ & $3.36 \mathrm{~B} \mathrm{c}$ & $5.52 \mathrm{~A} \mathrm{a}$ & $1.20 \mathrm{C} \mathrm{c}$ & $3.70 \mathrm{~B} \mathrm{bc}$ & $5.18 \mathrm{~A} a$ & $2.31 \mathrm{~B} \mathrm{~b}$ & $0.69 \mathrm{Cd}$ & $5.29 \mathrm{~A}$ a \\
\hline
\end{tabular}


Following roasting or blanching, the content of $\alpha$-linolenic acid considerably increased in all cultivars, except for Refêgo, which showed an opposite response. Few studies found significant changes in the content of $\alpha$-linolenic acid after processing of almonds: Ghazzawi and Al-Ismail (2017) [37] recorded a slight increase in the content of linolenic acid after frying, but not after roasting; Schlörmann et al. (2015) [42] did not detect this fatty acid in raw and roasted almond samples. In fact, the low level of linolenic acid in several cultivars is likely responsible for the lack of data regarding the effects of processing on almond lipids. In walnut, increases or decreases in the content of $\alpha$-linolenic were found, depending on the roasting conditions [42,44]; In cashew, pistachio and pine nuts, these changes depended on the processing method [37]. In all cultivars, the amount of $\gamma$-linolenic acid rose or tended to increase after roasting (except for Refêgo in which it was not detected) and blanching (except for a decrease in Casanova). Additional fatty acids whose contents rose in all cultivars after roasting or blanching were erucic and nervonic acids. In the case of nervonic acid however, two exceptions were found: for a decrease in Refêgo after roasting, and a decrease in Ferragnès after blanching.

Interestingly, three long-chain polyunsaturated fatty acids are reported in this study that were undetected in raw almond kernels, and only emerge after processing. These included after roasting cis-11,14-eicosadienoic acid in. Casanova, Glorieta and Pegarinhos, cis-8,11,14-eicosatrienoic in Molar and Pegarinhos, andcis-5,8,11,14,17-eicosapentaenoic acid in Molar and Pegarinhos. With the exception of cis-11,14-eicosadienoic acid in Casanova, the three long-chain polyunsaturated fatty acids were detected in all cultivars following blanching.

\subsection{Health Lipid Indices of Almond Cultivars}

The content of saturated fatty acids (SFA) ranged from $4.36 \%$ in Glorieta to $18.04 \%$ in Molar (Table 3). SFA values were close to the threshold of $10 \%$ [40] and similar to those reported for the same cultivars by Oliveira et al. (2019) [15]. Research shows that high-fat fruit rich in SFA are less susceptible to lipid oxidation and rapid deterioration than low-fat fruit. Similarly, Molar's ability to resist oxidation than the other cultivars can be deduced from its high SFA content. Significant differences in cultivars relative to the content of monounsaturated fatty acids (MUFA) were also observed and values ranged from $65.58 \%$ to $78.09 \%$, in agreement with previous studies $[15,45]$. The content of polyunsaturated fatty acids (PUFA) ranged from $16.37 \%$ in Molar to $23.81 \%$ (Table 3). It is reported that nuts with high levels of MUFA (oleic acid in particular) are more stable and less susceptible to oxidative rancidity than those with high levels of PUFA [29,39]. In the present study, PUFA/MUFA values were similar for all cultivars and lower than 1, indicating good oil stability. The UFA/SFA ratio is another parameter related to the shelf life of food products; the lower the UFA/SFA ratio, the higher the prospective shelf life of almonds [46]. In this study, the lowest UFA/SFA value of $4.57 \%$ was calculated for Molar, which indicates its ability to withstand long storage periods. It is important to note that despite their relevance to the oxidative stability of almonds, SFA at high levels are harmful to the cardiovascular system [29].

The atherogenicity index (AI) is defined as the relationship between the main saturated (pro-atherogenic) and unsaturated (anti-atherogenic) fatty acids. The lower the AI values, the less likely the cardiovascular risk [47]. AI values were similar for all cultivars with the exception of Molar which obtained the highest value due to the abundance of SFA (Table 3). The thrombogenicity index (TI) indicates the propensity of lipids to form clots in blood vessels and is defined as the relationship between saturated (pro-thrombogenetic) and unsaturated (MUFAs, PUFAs-n6, and PUFAs-n3; anti-thrombogenetic) fatty acids. The lower the TI values, the healthier the oil or the fat contained in a food (Ulbricht and Southgate, 1991). The "cultivar" factor significantly affected TI and the highest value of 0.16 was calculated for Molar. The hypocholesterolemic/hypercholesterolemic $(\mathrm{h} / \mathrm{H})$ ratio estimates the functional role of fatty acids in the metabolism of lipoproteins involved in the transport of plasmatic cholesterol. Thus, the $\mathrm{h} / \mathrm{H}$ can be used as an indicator for the risk level of cardiovascular disease incidence [48] (Santos-Silva et al., 2002). Glorieta obtained the highest $\mathrm{h} / \mathrm{H}$ value indicating its ability to contribute to improved cardiovascular health. 
Table 3. Contents of the main (most abundant and/or most affected) fatty acids in almond oil extracted from raw, roasted, and blanched kernels (\%, mean, $\mathrm{n}=3$ ) Different small letters in front of mean within a row indicate significant differences among cultivars for the same treatment. Different capital letters in front of mean within a row indicate significant differences among treatments for the same cultivar ( $p<0.05$, ANOVA Tukey's test). n.d.-not detected. SFA-saturated fatty acids; MUFA-monounsaturated fatty acids; PUFA-polyunsaturated fatty acids; AI-atherogenic index; TI-thrombogenic index; $\mathrm{h} / \mathrm{H}$-hypocholesterolemic/hypercholesterolemic index.

\begin{tabular}{|c|c|c|c|c|c|c|c|c|c|c|c|c|c|c|c|c|c|c|}
\hline \multirow[t]{2}{*}{ Cultivar } & \multicolumn{3}{|c|}{ Casanova } & \multicolumn{3}{|c|}{ Ferragnès } & \multicolumn{3}{|c|}{ Glorieta } & \multicolumn{3}{|c|}{ Molar } & \multicolumn{3}{|c|}{ Pegarinhos } & \multicolumn{3}{|c|}{ Refêgo } \\
\hline & Raw & Roasted & Blanched & Raw & Roasted & Blanched & Raw & Roasted & Blanched & Raw & Roasted & Blanched & Raw & Roasted & Blanched & Raw & Roasted & Blanched \\
\hline SFA & $8.01 \mathrm{Bc}$ & $\mathrm{Aa}$ & $7.68 \mathrm{~B} \mathrm{~d}$ & $12.18 \mathrm{~A} \mathrm{~b}$ & $9 \mathrm{C} \mathrm{d}$ & $\begin{array}{ll}B \mathrm{~B} b \\
\end{array}$ & $4.36 \mathrm{C} \mathrm{d}$ & Bc & $44 \mathrm{Ac}$ & $18.04 \mathrm{~A}$ a & c & $4 \mathrm{~B} \mathrm{~b}$ & $78 \mathrm{~A} \mathrm{c}$ & $\mathrm{cd}$ & $74 \mathrm{Acd}$ & $24 \mathrm{~B} \mathrm{C}$ & $8.07 \mathrm{Ca}$ & $2.62 \mathrm{~A} \mathrm{a}$ \\
\hline MUFA & $3 \mathrm{Aab}$ & 4 & $9 \mathrm{Aa}$ & $\mathrm{b}$ & 5 & $63 \mathrm{~B} C$ & $09 \mathrm{~A}$ a & $\mathrm{CC}$ & b & $\mathrm{Ab}$ & b & $\mathrm{Cd}$ & $41 \mathrm{~A} \mathrm{~b}$ & $\mathrm{Cd}$ & $\mathrm{Bcd}$ & $68.58 \mathrm{~B} \mathrm{~b}$ & $\mathrm{Aa}$ & $2 \mathrm{Cb}$ \\
\hline PUFA & $6 \mathrm{~B} a \mathrm{abc}$ & $48.34 \mathrm{~A}$ b & $144 \mathrm{~B} C$ & $20.88 \mathrm{C}$ abc & $40.78 \mathrm{~A} \mathrm{~cd}$ & $37.84 \mathrm{~B}$ a & $.55 \mathrm{C} \mathrm{bc}$ & $47.28 \mathrm{~A} \mathrm{bc}$ & $29.36 \mathrm{~B} \mathrm{~b}$ & $16.37 \mathrm{C} c$ & $39.12 \mathrm{~B} \mathrm{~d}$ & $41.39 \mathrm{~A}$ a & $23.81 \mathrm{C}$ a & 62.1A a & $40.80 \mathrm{~B} \mathrm{a}$ & $22.17 \mathrm{~B}$ ab & $9.04 \mathrm{Ce}$ & $26.06 \mathrm{~A} \mathrm{bc}$ \\
\hline PUFA/MUFA & $0.30 \mathrm{~B} a \mathrm{ab}$ & $1.18 \mathrm{~A} \mathrm{~b}$ & $0.34 \mathrm{~B} \mathrm{~d}$ & $2 \mathrm{~B} \mathrm{ab}$ & $6 \mathrm{Ac}$ & $0.733 \mathrm{~A} \mathrm{~b}$ & $0.225 \mathrm{Cb}$ & $1.03 \mathrm{~A} \mathrm{bc}$ & $0.476 \mathrm{~B} \mathrm{c}$ & $0.25 \mathrm{C} \mathrm{ab}$ & $0.72 \mathrm{~B} \mathrm{c}$ & $0.872 \mathrm{~A} a$ & $0.35 \mathrm{C} \mathrm{a}$ & $1.98 \mathrm{Aa}$ & $0.81 \mathrm{~B} \mathrm{ab}$ & $0.32 \mathrm{~B} \mathrm{ab}$ & $0.11 \mathrm{Cd}$ & $0.425 \mathrm{Acd}$ \\
\hline UFA/SFA & $0 \mathrm{Ab}$ & & $2 \mathrm{~A} a$ & & $8 \mathrm{Aa}$ & $\mathrm{BC}$ & $21.96 \mathrm{~A}$ a & $14.07 \mathrm{~B} \mathrm{bc}$ & $10.08 \mathrm{Cb}$ & $4.57 \mathrm{C} \mathrm{d}$ & $14.38 \mathrm{~A} \mathrm{bc}$ & $8.07 \mathrm{~B} \mathrm{~cd}$ & $10.39 \mathrm{~B} \mathrm{~b}$ & $15.28 \mathrm{~A} \mathrm{ab}$ & $10.47 \mathrm{~B} \mathrm{~b}$ & $9.85 \mathrm{~B} \mathrm{~b}$ & $11.39 \mathrm{~A} \mathrm{~cd}$ & $6.929 \mathrm{Cd}$ \\
\hline AI & $7 \mathrm{Ab}$ & $0.02 \mathrm{Cb}$ & $0.14 \mathrm{~A} \mathrm{a}$ & $.09 \mathrm{~A} \mathrm{~b}$ & $4 \mathrm{~B} \mathrm{~b}$ & $0.04 \mathrm{~B} \mathrm{c}$ & $0.09 \mathrm{~A} \mathrm{~b}$ & $0.03 \mathrm{~B} \mathrm{~b}$ & $0.06 \mathrm{~A} \mathrm{bc}$ & $0.73 \mathrm{~A} a$ & $0.06 \mathrm{~B} \mathrm{~b}$ & $0.04 \mathrm{~B} \mathrm{c}$ & $0.14 \mathrm{~A} \mathrm{~b}$ & $0.01 \mathrm{Cb}$ & $0.05 \mathrm{~B} \mathrm{c}$ & $0.13 \mathrm{~B} \mathrm{~b}$ & $0.43 \mathrm{~A} \mathrm{a}$ & $0.08 \mathrm{Cb}$ \\
\hline TI & $\mathrm{Ab}$ & $1 \mathrm{Cc}$ & $0.04 \mathrm{~B} \mathrm{ab}$ & $0.06 \mathrm{Ac}$ & $0.02 \mathrm{~B} \mathrm{C}$ & $0.03 \mathrm{~B} \mathrm{~b}$ & $0.05 \mathrm{Ac}$ & $0.02 \mathrm{~B} \mathrm{C}$ & $0.04 \mathrm{~A} \mathrm{~b}$ & $0.16 \mathrm{~A} a$ & $0.03 \mathrm{~B} \mathrm{~b}$ & $0.03 \mathrm{~B} \mathrm{~b}$ & $0.09 \mathrm{~A} \mathrm{~b}$ & $0.01 \mathrm{Cc}$ & $0.03 \mathrm{~B} \mathrm{~b}$ & $0.05 \mathrm{~B} \mathrm{C}$ & $0.09 \mathrm{~A}$ a & $0.05 \mathrm{~B}$ a \\
\hline $\mathrm{hH}$ & $13.19 \mathrm{~B} \mathrm{~cd}$ & $34.22 \mathrm{~A} \mathrm{ab}$ & $14.45 \mathrm{~B} \mathrm{~b}$ & 19.12b B & $29.39 \mathrm{~b} \mathrm{~A}$ & $27.31 \mathrm{~A}$ a & $32.03 \mathrm{~A} \mathrm{a}$ & $34.02 \mathrm{~A} a b$ & $27.29 \mathrm{~B} \mathrm{a}$ & $9.08 \mathrm{C} \mathrm{d}$ & $17.83 \mathrm{~B} \mathrm{c}$ & $24.82 \mathrm{~A} \mathrm{ab}$ & $13.56 \mathrm{C} \mathrm{cd}$ & $39.91 \mathrm{~A}$ a & $22.38 \mathrm{~B} \mathrm{ab}$ & $15.91 \mathrm{~B} \mathrm{bc}$ & $12.70 \mathrm{C} \mathrm{c}$ & $18.46 \mathrm{~A} \mathrm{ab}$ \\
\hline
\end{tabular}




\subsection{Effects of Roasting and Blanching on Almond Health Lipid Indices}

With some exceptions, blanching similarly affected health lipid indices of all almond cultivars (Table 3). Casanova, Ferragnès, Glorieta, Molar, and Pegarinhos exhibited similar responses after roasting, in contrast to Refêgo. Besides Casanova and Glorieta in which increases were observed, there was a decrease in the content of SFA in almond cultivars after roasting. Furthermore, almond cultivars showed a decreasing trend in SFA content after blanching with the exception of Glorieta and Refêgo. The content of MUFA generally decreased in almond samples after roasting and blanching except for Refêgo after roasting; the inverse was true for the PUFA content. The most common responses observed after nut processing are increases in SFA [37,41,42] and decreases in PUFA and MUFA [37] levels. In the study by Valdés et al. (2015) [6], the contents of SFA and MUFA increased while that of PUFA decreased in almond after processing. In the present study, both increases and decreases were found in relation to the contents of SFA, MUFA, and PUFA. Beside the "cultivar" effect, these variations are most likely related to processing conditions and basal levels of all fatty acids, but also to the fact that minor fatty acids are not usually quantified by investigators.

Similar to the PUFA content, an increasing trend was observed in relation to the PUFA/MUFA ratio of all cultivar after processing with the exception of that of Refêgo after roasting. The lowest PUFA/MUFA value obtained after roasting was found for Refêgo. In the case of blanching, both Refêgo and Casanova achieved the lowest PUFA/MUFA. The above observation indicates that these cultivars are most likely to be less prone to oxidation after processing. After roasting, the UFA/SFA ratio increased in four cultivars (Ferragnès, Molar, Pegarinhos, and Refêgo) and decreased in two cultivars (Casanova and Glorieta). Both Casanova and Refêgo attained the lowest UFA/SFA values, as also observed with the PUFA/MUFA values. Blanching differentially affected the UFA/SFA ratio: The UFA/SFA ratio calculated for Refêgo and Glorieta decreased whereas an increase was recorded for Ferragnès and Molar. Casanova and Pegarinhos on the other hand showed no significant changes relative to the UFA/SFA ratio.

Health lipid indices were significantly affected by both processing treatments. The AI and TI values decreased or tended to decrease in all cultivars with the exception of Refêgo in which an increase was observed after roasting. The $\mathrm{h} / \mathrm{H}$ ratio on the other hand generally increased after roasting and blanching although some exceptions were observed. For instance, a decrease in the $\mathrm{h} / \mathrm{H}$ ratio was observed for Refêgo and Glorieta after roasting and blanching respectively. In roasted kernels, AI and TI values were similar for all cultivars with the exception of Refêgo which obtained high values. These high values of AI and TI observed for Refêgo can be associated with increased risks to cardiovascular problems; indeed, Refêgo exhibited the lowest $\mathrm{h} / \mathrm{H}$ value after roasting. Overall, the highest $\mathrm{h} / \mathrm{H}$ value was calculated for the oil extracted from roasted kernels of Pegarinhos.

\subsection{Sensorial Analysis of Raw Almond Samples}

The sensory profiles of raw kernels from all almond cultivars studied were similar to that shown in Figure 1A. Significant differences were observed relative to skin color, bitter almond flavor and bitter taste. Skin color was found to be darker in the foreign cultivars (Glorieta and Ferragnès) than the Portuguese cultivars. Bitter almond flavor and bitter taste were more associated with Molar and Pegarinhos than the rest of the cultivars. The primary taste characteristics easily identified by consumers are sweetness and astringency followed by bitterness or sourness [49]. The bitter taste derived from eating raw kernels of Molar and Pegarinhos might be due to a high concentration of benzaldehyde in these cultivars. Indeed, benzaldehyde is a chemical with a bitter taste and a low odor threshold [50]. Several Portuguese almond cultivars including Pegarinhos have high levels of benzaldehyde [14]. 


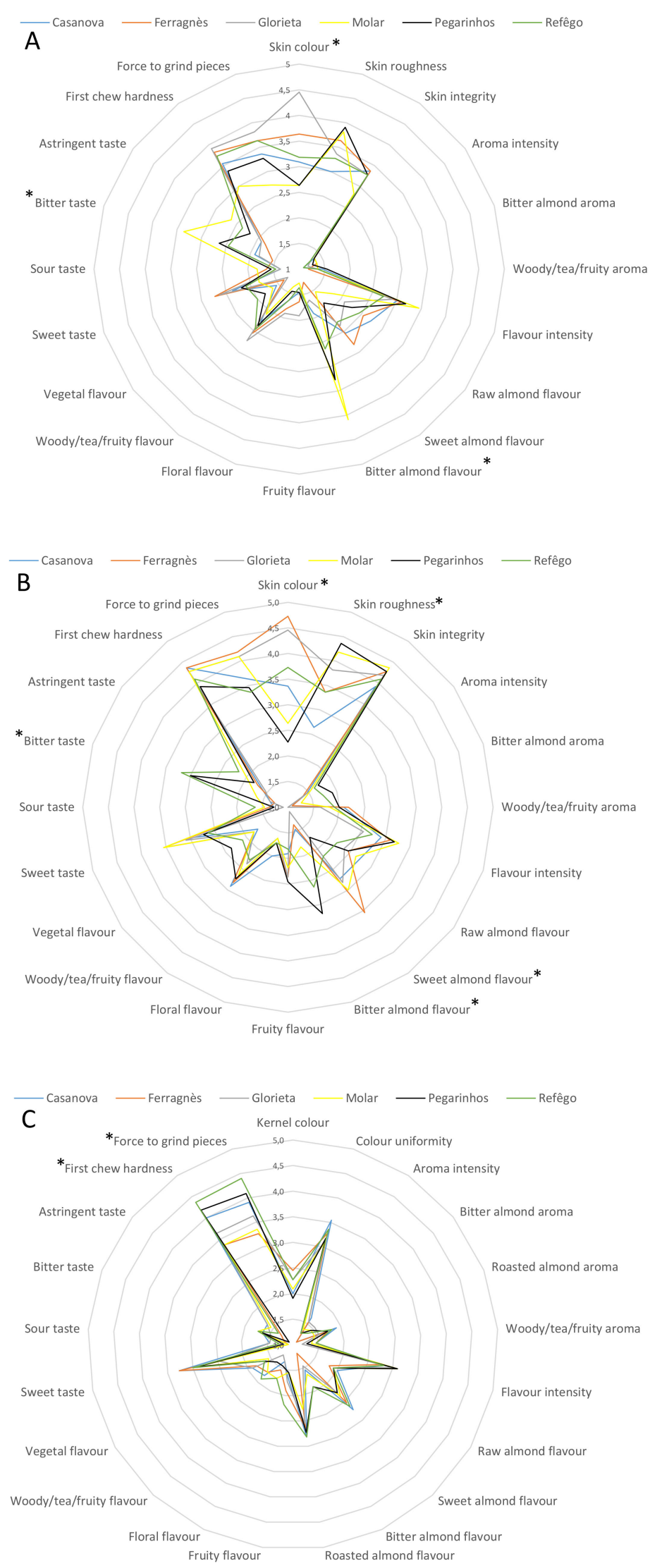

Figure 1. Spider plot of the sensory profile of raw (A), roasted (B) and blanched (C) almond kernles. Asterisks $\left({ }^{*}\right)$ indicate represent significant differences among cultivars $p<0.05$, ANOVA Tukey's test. 


\subsection{Effects of Roasting and Blanching on Sensory Characteristics of Almonds}

The main sensory attributes differentiating the six almond cultivars after roasting were found to be skin color, bitter almond flavor, bitter taste, skin roughness, and sweet almond flavor (Figure 1B). Skin color rated highest for the foreign cultivars (Ferragnès and Glorieta) and lowest for Molar and Pegarinhos. Relative to skin roughness, the skin of Molar and Pegarinhos were found to be rough whereas that of Casanova was found to be smooth. The sweet almond flavor was strongly associated with Ferragnès and barely perceived for Pegarinhos. Pegarinhos and Refêgo achieved the highest rating for bitter almond flavor and bitter taste whereas Glorieta was rated lowest for bitter almond flavor. Roasting is known to increase the levels of compounds such as pyrazines, furans, and pyrrols in food products. The above compound represents three groups of chemicals with nutty and roasted aromas [50,51] that are formed through non-enzymatic Maillard browning reactions [52]; these compounds are also known to enhance the aromas of roasted almonds [40]. In our previous work [14], pyrazines were not detected in any of the six cultivars studied; it was, however, detected in the Portuguese cultivar Amendoão. Xiao et al. (2014) [53] reported decreases in the levels of benzaldehyde and several alcohols in food products after roasting. For the six cultivars object of the present study an increase in the amount of benzaldehyde was observed after roasting. The above observation may partly account for the significant differences among cultivars relative to bitter sensorial characteristics.

In the case of blanched kernels, differences in sensorial characteristics among cultivars were only recorded for textural parameters, namely first chew hardness and force to grind pieces (Figure 1C). Both characteristics rated highest for Refêgo and Pegarinhos and lowest for Ferragnès and Molar. These changes in textural parameters are likely due to the low water content of blanched kernels which were subjected to two processing steps both involving heating. Indeed, water is known to directly influence the hardness, crispness, crunchiness and toothpack attributes of almonds [54]. Consumers usually show a preference for crispy, crunchy [54,55], and sweet almonds [55]. Hence, good ratings by the panelist for blanched kernels relative to textural properties could have positive implications for the almond industry. Indeed, hard, fracturable and crunchy almonds are used as cooking ingredients to improve food texture while moist and chewy almonds are suitable for beverages [56].

\subsection{Multivariate Analyses of Bioactive Compounds, Antioxidant Activities and Fatty Acids Data}

All data obtained (with the exception of those from sensorial analyses) were submitted to linear discriminant analysis (LDA) to identify parameters that could be used to differentiate both the almond cultivars and the processing methods. Seventeen variables which differed significantly between cultivars and processing treatments were selected using LDA and subjected to Principal component analysis (PCA) (Figure 2). PCA generated a 17-component model that explained $100 \%$ of the total variance in the data. The first and second components accounted for $43.398 \%$ and $17.992 \%$ (for a total of $61.318 \%$ ) of the total variance respectively (Figure 2a). All cultivars and processing methods were well separated on the PCA except for roasted and blanched kernels of Refêgo and Casanova respectively. Indeed, the loading plot in Figure 2B showed that palmitic acid, MUFA, AI and TI contributed the most to the separation of Refêgo from other cultivars. Blanched kernels of Casanova on the other hand contained high levels of C18:1 (elaidic + oleic acid), palmitic acid, MUFA and AI and low levels of $\alpha$-linolenic acid. 


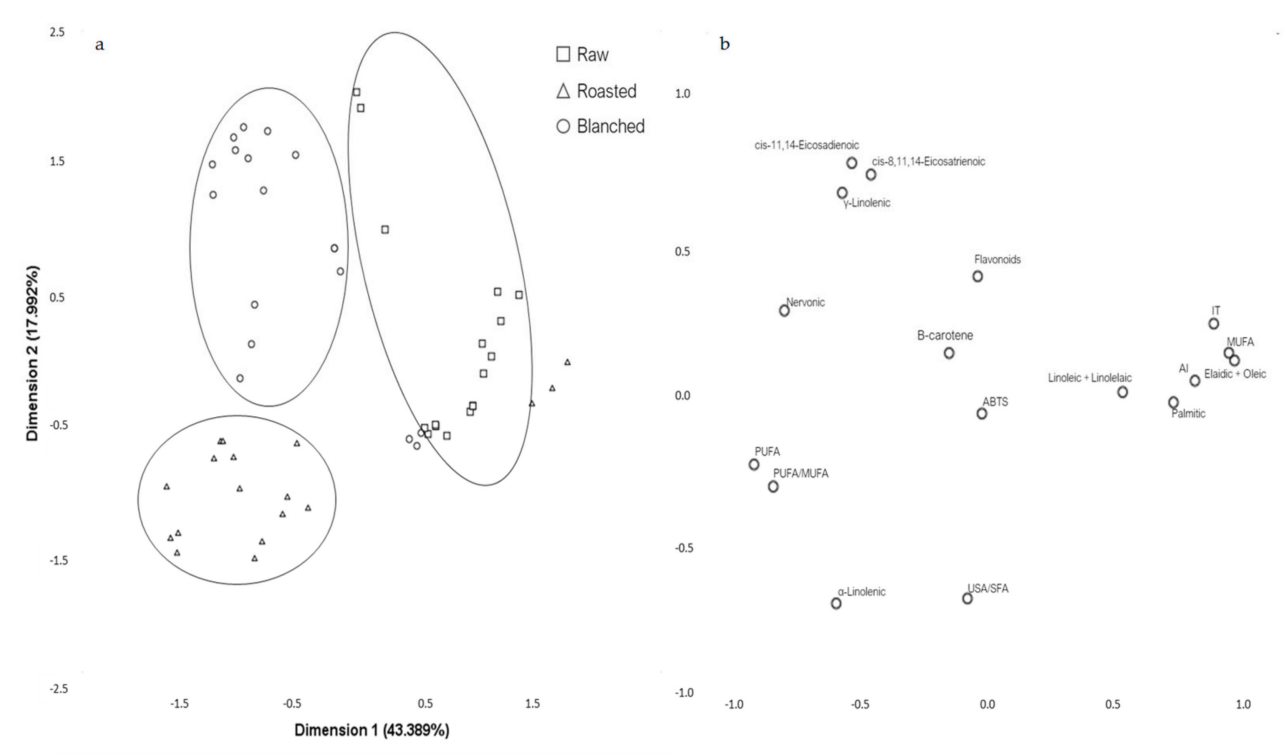

Figure 2. Principal component analysis of bioactive compounds, antioxidant activities and fatty acids data from raw, roasted and blanched almond kernels: scores plot of the first and second principal components (a) showing the clustering of cultivars and treatments; loadings plot (b) reflecting the influence of parameters on the separation of samples.

\section{Materials and Methods}

\subsection{Almond Samples and Processing Treatments}

Almond samples were obtained in 2019 from growers in the municipality of Torre de Moncorvo (Northeastern Portugal, $41^{\circ} 10^{\prime} 26^{\prime \prime} \mathrm{N} 7^{\circ} 3^{\prime} 0^{\prime \prime} \mathrm{W}$ ), and were constituted of fruit of the Portuguese traditional cultivars (Casanova, Molar, Pegarinhos and Refêgo), French cultivar Ferragnès and Spanish cultivar Glorieta. Samples from each cultivar were harvested at commercial maturity and subdivided into three parts to obtain three replicates. Before processing, almond fruit were deshelled to obtain raw kernels which included the skin. Medium roasting of the kernels was conducted at $138^{\circ} \mathrm{C}$ for 33 min [53]. Blanching was performed using the method described by Milbury et al. [18] with some modifications; kernels were immersed in boiling water for $30 \mathrm{~s}$ and the skins were removed by hand. Deskinned kernels were left to dry at room temperature and this was followed by roasting at $138^{\circ} \mathrm{C}$ for $33 \mathrm{~min}$. These treatments were selected due to their extensive use in industrial processing of almonds. Raw, roasted, and blanched kernels were finely ground to obtain a fresh flour for chemical analyses.

\subsection{Bioactive Compounds: Total Phenolic and Total Flavonoid Contents}

An "antioxidant extract" was prepared by vortex-mixing $40 \mathrm{mg}$ of the sample with $1 \mathrm{~mL}$ of $70 \%$ methanol. The mixture obtained was heated for $30 \mathrm{~min}$ at $70^{\circ} \mathrm{C}$, and then centrifuged (Eppendorf Centrifuge $5804 \mathrm{R}$, Hamburg, Germany) at $25,200 \mathrm{rcf}$ for $15 \mathrm{~min}$ at $1{ }^{\circ} \mathrm{C}$. The supernatant which constituted the "antioxidant extract" was filtered (Spartan filters $0.2 \mathrm{~mm}$ ) into HPLC amber vials and used for the determination of the total phenolic content, total flavonoid content, and antioxidant activities. A slight modification of the methodology of Singleton and Rossi [26] (1965) was used for quantification of total phenolics as follows: $20 \mu \mathrm{L}$ of the "antioxidant extract" was mixed with $100 \mu \mathrm{L}$ of Folin-Ciocalteu phenol reagent (1:10 v/v/in bidistilled $\mathrm{H} 2 \mathrm{O}$ ) and $80 \mu \mathrm{L}$ of $7.5 \%$ Na2CO3 in a 96-well microplate (Multiskan ${ }^{\mathrm{TM}}$ FC Microplate Photometer, Waltham, MA, USA). The microplate was incubated in the dark for $15 \mathrm{~min}$ at $45^{\circ} \mathrm{C}$. Afterward, the absorbance values against the blank value were recorded at $765 \mathrm{~nm}$ in a microplate reader (Multiskan GO Microplate Spectrophotometer, Thermo Scientific, Vantaa, Finland). Simultaneously, gallic acid solutions of different concentrations 
were analyzed and a calibration curve was constructed for quantitation purposes. The total phenolic content was expressed as mg gallic acid equivalent (GAE)/g f.w (fresh weight). The total flavonoid content was determined using the colorimetric method described in Dewanto et al. [21] with some modifications. In a 96-well microplate, $25 \mu \mathrm{L}$ of "antioxidant extract" was combined with $100 \mu \mathrm{L}$ of water and $10 \mu \mathrm{L}$ of NaNO2. The microplate was placed in the dark at room temperature. After $5 \mathrm{~min}$, $15 \mu \mathrm{L}$ of $10 \% \mathrm{AlCl} 3$ was added to the wells and the microplate was incubated again at room temperature in the dark for $6 \mathrm{~min}$. Then, $50 \mu \mathrm{L}$ of $\mathrm{NaOH} 1 \mathrm{M}$ and $50 \mu \mathrm{L}$ of water were added. The absorbance values against the blank value were recorded at $510 \mathrm{~nm}$. Simultaneously, catechin solutions of different concentrations were analyzed. The total flavonoid content was quantified using the calibration curve of catechin and expressed as mg catechin equivalent (CE)/g f.w.

\subsection{Antioxidant Activities}

The 2,2'-azino-bis(3-ethylbenzothiazoline-6-sulfonic) acid (ABTS) radical scavenging activity was evaluated in a 96-well microplate using the method of Re et al. [57]. An ABTS radical solution was prepared by mixing $7 \mathrm{mM}$ of ABTS at $\mathrm{pH} 7.4(5 \mathrm{mM} \mathrm{NaH} 2 \mathrm{PO} 4,5 \mathrm{mM} \mathrm{Na} 2 \mathrm{HPO} 4$, and $154 \mathrm{mM} \mathrm{NaCl})$ with $2.5 \mathrm{mM} \mathrm{K} 2 \mathrm{~S} 2 \mathrm{O} 8$. After incubation in the dark at room temperature for $16 \mathrm{~h}$, the ABTS solution was diluted with ethanol until an absorbance of $0.70 \pm 0.02$ units at $734 \mathrm{~nm}$ obtained. In each microplate well, $15 \mu \mathrm{L}$ of the "antioxidant extract" was combined with $285 \mu \mathrm{L}$ of freshly prepared ABTS solution. The mixtures were incubated at room temperature in the dark for $10 \mathrm{~min}$ and absorbance values were measured at $734 \mathrm{~nm}$. ABTS activity was expressed using the linear calibration curve of trolox as $g$ trolox equivalent/g f.w. The 2,2-diphenyl-1-picrylhydrazyl (DPPH) antioxidant activity assay was performed by spectrophotometry as described by Siddhraju \& Becker [58]. Briefly, $20 \mu \mathrm{L}$ of the "antioxidant extract" and $280 \mu \mathrm{L}$ of freshly prepared methanolic radical DPPH solution $(6 \times 10-5 \mathrm{~mol} / \mathrm{L})$ were introduced into a 96-well microplate. The microplates were covered with a foil paper and left for $30 \mathrm{~min}$ at room temperature. The reduction in absorbance was measured at $517 \mathrm{~nm}$. The DPPH activity was expressed using the linear calibration curve of trolox as $\mathrm{g}$ trolox equivalent/g f.w. To assess the ability of almond extracts to inhibit lipid oxidation, the $\beta$-carotene-linoleic acid bleaching assay was performed using the method described by Salleh et al. [59] with minor modifications as follows: a mixture of $\beta$-carotene and linoleic acid was prepared by adding $0.5 \mathrm{mg} \beta$-carotene with $1 \mathrm{~mL}$ chloroform (HPLC grade), $25 \mu \mathrm{L}$ linoleic acid and $200 \mathrm{mg}$ Tween 40 . After complete evaporation of the chloroform under vacuum, $100 \mathrm{~mL}$ of water was added to the residue which was gently stirred to form a yellowish emulsion. To $50 \mu \mathrm{L}$ of the "antioxidant abstract" were added $0.25 \mu \mathrm{L}$ of the yellowish emulsion. After thorough mixing, the mixture was incubated in a water bath at $50^{\circ} \mathrm{C}$ for $2 \mathrm{~h}$ followed by the measurement of absorbance values at $470 \mathrm{~nm}$ against a blank. Percentage inhibition (I\%) of lipid peroxidation was calculated using the following equation:

$$
\mathrm{I} \%=(\mathrm{A} \beta \text {-carotene after } 2 \mathrm{~h} / \text { Ainitial } \beta \text {-carotene }) \times 100 ;
$$

where $A \beta$-carotene after $2 \mathrm{~h}$ is the absorbance value of $\beta$-carotene after $2 \mathrm{~h}$ of incubation and Ainitial $\beta$-carotene is the absorbance value of $\beta$-carotene before incubation.

\subsection{Fatty Acids}

Total oil was extracted from $5 \mathrm{~g}$ almond sample with petroleum ether in a Soxhlet apparatus [30] operating at $135^{\circ} \mathrm{C}$ for $2 \mathrm{~h}$. The extracted oil was used to prepare methyl esters of the corresponding fatty acids (FAME) according to EEC (1991) [60]. The resulting FAMEs were analyzed with a Shimadzu GC-2010 Plus gas chromatograph (Shimadzu, Kyoto, Japan) equipped with a flame ionization detector (FID-2010 Plus). Component peak separation was obtained on a DB-225MS capillary column $(0.25 \mu \mathrm{m}$, $30 \mathrm{~m} \times 0.25 \mathrm{~mm}$ i.d., Agilent Technologies, Wilmington, DE, USA). Helium was used as the carrier gas ( $200 \mathrm{kPa}$, constant flow, $1 \mathrm{~mL} / \mathrm{min}$ ). The temperature of the column was maintained for $10 \mathrm{~min}$ at $200{ }^{\circ} \mathrm{C}$ and then increased to $220^{\circ} \mathrm{C}$ at $5^{\circ} \mathrm{C}$ per min. The inlet and detector temperatures were set 
at $270{ }^{\circ} \mathrm{C}$. The split ratio was 5:1 and the injected volume was $1.0 \mu \mathrm{L}$. The constituent FAMEs were identified by comparison with standard FAME mixtures (FAME 37, Supelco, Bellefonte, PA, USA). The amount of each FAME was expressed as a weight percentage (\%) of the total FAMEs represented in the chromatogram, with the assumption that no other major lipids and other substances were present in the almond oils. In several samples, the peaks for elaidic and oleic acids co-eluted, as well as the peaks for linoleic and linolelaidic acids. Thus, peak areas corresponding to these compounds were summed in the calculations. Fatty acid data was used for the calculation of several health lipid indices. The atherogenic index (AI) and the thrombogenic index (TI) were calculated using the equations proposed by Ulbricht and Southgate [47].

The hypocholesterolemic/hypercholesterolemic $(\mathrm{h} / \mathrm{H})$ index indicates the sample's potential to provide good over bad cholesterol and was calculated using the equation proposed by Santos-Silva et al. [48].

\subsection{Sensorial Analysis}

Raw, roasted, and blanched almond kernels were evaluated by a panel of 12 tasters from Departamento de Biologia e Ambiente (DeBA-ECVA), Universidade de Trás-os-Montes e Alto Douro in Portugal. The panelist was well trained and have participated in sensory tests from previous studies. The test took place between 4:00 pm and 5:00 pm in a room with regulated temperature and air pressure/flow. Almond kernels were presented to the tasters in white pyrex dishes. The testing environment and procedure/equipment were all following ISO 8589:2007. Three tasting sessions were carried out; the first, second and third sessions were done using raw, roasted, and blanched almonds respectively. A Quantitative Descriptive Analysis (QDA) was performed using 20 descriptors adapted from Civille et al. [49] and a structured scale from 1 (least intense) to 5 (most intense) for each descriptor (ISO 4121:2003).

\subsection{Statistical Analyses}

Data are presented as mean (f.w) of three replicates. Differences among means were determined by analysis of variance (ANOVA) using SPSS (Statistical Package for Social Sciences) 19.0 (IBM Corporation, New York, NY, USA). The fulfillment of ANOVA requirements, namely the normal distribution of the residuals and the homogeneity of variance was evaluated using the Shapiro-Wilk's test $(n<50)$ and the Levene's test, respectively. The Tukey test was used for the comparison of means which were considered different at a 5\% significance level. A stepwise linear discriminant analysis (LDA) was performed to find the linear combination of parameters that best characterized raw, roasted, or blanched samples. The LDA involved the use of a combination of forward selection and backward elimination procedures for variable separation. Before selecting a new variable to be included in the model, it was ascertained that all previously selected variables were still significant which enabled identification of all possible significant variables. The Wilk's lambda test was applied for variable selection through verification of the significance of each canonical discriminant functions using the probabilities $\mathrm{F}=3.84$ to add and $\mathrm{F}=2.71$ to remove. To avoid overoptimistic data modulation, the model performance was assessed using a leave-one-out cross validation procedure. Principal component analysis (PCA) was performed by plotting all data in a multidimensional space using LDA significant variables as dimensions (factor scores). With this approach, the number of variables was reduced to a smaller number of newly derived variables (principal component or factors) that adequately summarized the original information, and highlighted underlying patterns in the data collected. Scree plots were used for retaining the most useful factors taking into consideration eigenvalues greater than one and internal consistencies of high Cronbach $\alpha$ values.

\section{Conclusions}

This study evaluated the effects of processing (roasting and blanching) on the levels of phenolics, flavonoids and fatty acids in four Portuguese (Casanova, Molar, Pegarinhos and Refêgo) and two 
foreign (Ferragnès and Glorieta) almond cultivars, as well as on the antioxidant activities and sensorial characteristics of kernels. Antioxidant activities and levels of bioactive compounds were generally enhanced following roasting but reduced following blanching. The increased antioxidant activity upon roasting may at first seem unexpected, as heat could be envisaged to decrease (oxidize) phenolics. However, we interpret that roasting may either induce cell wall disruption allowing better antioxidant extraction, or may alternatively cause chemical alterations that result in heat-induced production of hyper-antiradical scavenging species. This might be linked to browning reaction s compounds, known to affect total phenolics quantification and antioxidant activities. Roasting and blanching reduced the ability of all cultivars to inhibit lipid oxidation. The fatty acid profiles of all cultivars were similar although raw kernels of Refêgo exhibited a high content of $\alpha$-linolenic acid. Glorieta and Molar were characterized by a low and a high content of SFA respectively. Both roasting and blanching led to significant changes in the fatty acid profiles of almonds, similar for all cultivars with the exception of Refêgo, and the effect of blanching was stronger than that of roasting. Relative to health lipid indices, Pegarinhos and Molar had better responses to roasting and blanching than the other cultivars. Very few significant differences in cultivars and treatments relative to sensorial characteristics were found. The negative features bitter taste and bitter almond flavor were noticed for raw kernels of Molar and Pegarinhos. Roasting of Ferragnès led to kernels with a strong sweet almond flavor, while blanching positively affected the textural properties of Refêgo and Pegarinhos. The findings of this study shed light on the nutritive and eating qualities of raw and processed kernels from neglected Portuguese almond cultivars, and highlight the potential use of these cultivars in various food industries.

Author Contributions: Conceptualization, I.O.; laboratory work, I.O., S.A., P.G. and A.S. writing-Original draft preparation, I.O. writing-Review and editing, I.O., A.S.M., S.A., A.V., P.G., H.T. and B.G.; supervision, B.G., A.S.M; All authors have read and agreed to the published version of the manuscript.

Funding: Ivo Oliveira is grateful to FCT—Fundação para a Ciência e a Tecnologia (FCT) for the financial support by national funds FCT/MCTES in the Post-doctoral Fellowship SFRH/BPD/111005/2015. This work is supported by National Funds by FCT-Portuguese Foundation for Science and Technology, under the project UIDB/04033/2020.

Conflicts of Interest: The authors declare no conflict of interest.

\section{References}

1. Rabadán, A.; Álvarez-Ortí, M.; Pardo, J. A comparison of the effect of genotype and weather conditions on the nutritional composition of most important commercial nuts. Sci. Horti. 2019, 244, 218-224. [CrossRef]

2. Berryman, C.; Preston, A.; Karmally, W.; Deckelbaum, R.; Kris-Etherton, P. Effects of almond consumption on the reduction of LDL-cholesterol: A discussion of potential mechanisms and future research directions. Nutr. Rev. 2011, 69, 171-185. [CrossRef] [PubMed]

3. Garrido, I.; Monagas, M.; Gómez-Cordovés, C.; Bartolomé, B. Polyphenols and antioxidant properties of almond skins: Influence of industrial processing. J. Food Sci. 2008, 73, C106-C115. [CrossRef] [PubMed]

4. Gradziel, T.M. Origin and dissemination of almond. In Horticultural Reviews; Janick, J., Ed.; John Wiley \& Sons, Inc.: Hoboken, NJ, USA, 2011; pp. 23-81.

5. Grundy, M.; Lapsley, K.; Ellis, P. A review of the impact of processing on nutrient bioaccessibility and digestion of almonds. Int. J. Food Sci. Technol. 2016, 51, 1937-1946. [CrossRef]

6. Valdés, A.; Beltrán, A.; Karabagias, I.; Badeka, A.; Kontominas, M.; Garrigós, M. Monitoring the oxidative stability and volatiles in blanched, roasted and fried almonds under normal and accelerated storage conditions by DSC, thermogravimetric analysis and ATR-FTIR. Eur. J. Lipid Sci. Technol. 2015, 117, 1199-1213. [CrossRef]

7. Severini, C.; Gomes, T.; de Pilli, T.; Romani, S.; Massini, R. Autoxidation of packed almonds as affected by Maillard reaction volatile compounds derived from roasting. J. Agric. Food Chem. 2000, 48, 4635-4640. [CrossRef]

8. Alamprese, C.; Ratti, S.; Rossi, M. Effects of roasting conditions on hazelnut characteristics in a two-step process. J. Food Eng. 2009, 95, 272-279. [CrossRef]

9. McClements, D.; Decker, E. Lípidos. In Fennema Quımica de los Alimentos, 3rd ed.; Samodaran, S., Parkin, K., Fennema, O., Eds.; Editorial Acribia: Zaragoza, Spain, 2010; pp. 155-214. 
10. Agila, A.; Barringer, S. Effect of roasting conditions on color and volatile profile including HMF level in sweet almonds (Prunus dulcis). J. Food Sci. 2012, 77, C461-C468. [CrossRef]

11. Beyhan, Ö.; Aktas, M.; Yilmaz, N.; Simsek, N.; Gerçekçioglu, R. Determination of fatty acid compositions of some important almond (Prunus amygdalus L.) varieties selected from Tokat province and Eagean region of Turkey. J. Med. Plants Res. 2011, 5, 4907-4911.

12. Zacheo, G.; Cappello, M.S.; Gallo, A.; Santino, A.; Cappello, A.R. Changes associated with postharvest ageing in almond seeds. LWT. Food Sci. Tech. 2000, 33, 415-423.

13. Oliveira, I.; Meyer, A.; Afonso, S.; Ribeiro, C.; Gonçalves, B. Morphological, mechanical and antioxidant properties of Portuguese almond cultivars. J. Food Sci. Technol. 2018, 55, 467-478. [CrossRef] [PubMed]

14. Oliveira, I.; Malheiro, R.; Meyer, A.S.; Pereira, J.A.; Gonçalves, B. Application of chemometric tools for the comparison of volatile profile from raw and roasted regional and foreign almond cultivars (Prunus dulcis). J. Food Sci. Technol. 2019, 56, 3764-3776. [CrossRef] [PubMed]

15. Oliveira, I.; Meyer, A.S.; Afonso, S.; Aires, A.; Goufo, P.; Trindade, H.; Gonçalves, B. Phenolic and fatty acid profiles, $\alpha$-tocopherol and sucrose contents, and antioxidant capacities of understudied Portuguese almond cultivars. J. Food Biochem. 2019, 43, e12887. [CrossRef] [PubMed]

16. Cabrita, L.; Apostolova, H.; Neves, A.; Leitão, J. Genetic diversity assessment of the almond (Prunus dulcis (Mill.) D.A. Webb) traditional germplasm of Algarve, Portugal, using molecular markers. Plant Genet. Resour. 2014, 12, 164-167. [CrossRef]

17. Barreira, J.; Ferreira, I.; Oliveira, M.; Pereira, J. Antioxidant activity and bioactive compounds of ten Portuguese regional and commercial almond cultivars. Food Chem. Toxicol. 2008, 46, 2230-2235. [CrossRef]

18. Milbury, P.; Chen, C.; Dolnikowski, G.; Blumberg, J. Determination of flavonoids and phenolics and their distribution in almonds. J. Agric. Food Chem. 2006, 54, 5027-5033. [CrossRef]

19. Yu, J.; Ahmedna, M.; Goktepe, I.; Dai, J. Peanut skin procyanidins: Composition and antioxidant activities as affected by processing. J. Food Compos. Anal. 2006, 19, 364-371. [CrossRef]

20. Rohn, S.; Buchner, N.; Driemel, G.; Rauser, M.; Kroh, L.W. Thermal degradation of onion quercetin glucosides under roasting conditions. J. Agric. Food Chem. 2007, 55, 1568-1573. [CrossRef]

21. Dewanto, V.; Wu, X.; Liu, R. Processed sweet corn has higher antioxidant activity. J. Agric. Food Chem. 2002, 50, 4959-4964. [CrossRef]

22. Bolling, B.; McKay, D.; Blumberg, J. The phytochemical composition and antioxidant actions of tree nuts. Asia Pacific J. Clin. Nutr. 2010, 19, 117.

23. Pereira, J.; Oliveira, I.; Sousa, A.; Ferreira, I.; Bento, A.; Estevinho, L. Bioactive properties and chemical composition of six walnut (Juglans regia L.) cultivars. Food Chem. Tox. 2008, 46, 2103-2111. [CrossRef] [PubMed]

24. Jesus, F.; Gonçalves, A.; Alves, G.; Silva, L. Exploring the phenolic profile, antioxidant, antidiabetic and antihemolytic potential of Prunus avium, vegetal parts. Food Res. Int. 2019, 116, 600-610. [CrossRef] [PubMed]

25. Tawaha, K.; Alali, F.Q.; Gharaibeh, M.; Mohammad, M.; El-Elimat, T. Antioxidant activity and total phenolic content of selected Jordanian plant species. Food Chem. 2007, 104, 1372-1378. [CrossRef]

26. Singleton, V.; Rossi, J. Colorimetry of total phenolics with phosphomolybdic-phosphotungstic acid reagents. Am. J. Enology Vitic. 1965, 16, 144-158.

27. Prior, R.L.; Wu, X.; Schaich, K. Standardized methods for the determination of antioxidant capacity and phenolics in foods and dietary supplements. J. Agric. Food Chem. 2005, 53, 4290-4302. [CrossRef] [PubMed]

28. Čolić, S.; Akšić, M.; Lazarević, K.; Zec, G.; Gašić, U.; Zagorac, D.; Natić, M. Fatty acid and phenolic profiles of almond grown in Serbia. Food Chem. 2017, 234, 455-463. [CrossRef] [PubMed]

29. Kodad, O.; Socias i Company R. Variability of oil content and of major fatty acid composition in almond (Prunus amygdalus Batsch) and its relationship with kernel quality. J. Agric. Food Chem. 2008, 56, 4096-4101. [CrossRef]

30. Kodad, O.; Estopanán, G.; Juan, T.; Alonso, J.M.; Espiau, M.T.; Socias i Company, R. Oil content, fatty acid composition and tocopherol concentration in the Spanish almond genebank collection. Sci. Hort. 2014, 177, 99-107. [CrossRef]

31. Barreira, J.; Casal, S.; Ferreira, I.; Peres, A.; Pereira, J.; Oliveira, M. Supervised chemical pattern recognition in almond (Prunus dulcis) portuguese PDO cultivars: PCA-and LDA-based triennial study. J. Agric. Food Chem. 2012, 60, 9697-9704. [CrossRef] 
32. Rabadán, A.; Álvarez-Ortí, M.; Gómez, R.; Pardo-Giménez, A.; Pardo, J. Suitability of Spanish almond cultivars for the industrial production of almond oil and defatted flour. Scientia Hort. 2017, 225, 539-546. [CrossRef]

33. Zamany, A.; Samadi, G.; Kim, D.; Keum, Y.; Saini, R. Comparative Study of Tocopherol Contents and Fatty Acids Composition in Twenty Almond Cultivars of Afghanistan. J. Am. Oil Chem. Soc. 2017, 94, 805-817. [CrossRef]

34. Zhu, Y.; Wilkinson, K.; Wirthensohn, M. Lipophilic antioxidant content of almonds (Prunus dulcis): A regional and varietal study. J. Food Compos. Anal. 2015, 39, 120-127. [CrossRef]

35. Askin, M.; Balta, M.; Tekintas, F.; Kazankaya, A.; Balta, F. Fatty acid composition affected by kernel weight in almond [Prunus dulcis (Mill.) DA Webb.] genetic resources. J. Food Compos. Anal. 2007, 20, 7-12. [CrossRef]

36. Virtanen, J.; Mursu, J.; Voutilainen, S.; Uusitupa, M.; Tuomainen, T. Serum omega-3 polyunsaturated fatty acids and risk of incident type 2 diabetes in men: The Kuopio Ischemic Heart Disease Risk Factor study. Diabetes Care 2014, 37, 189-196. [CrossRef]

37. Ghazzawi, H.A.; Al-Ismail, K. A comprehensive study on the effect of roasting and frying on fatty acids profiles and antioxidant capacity of almonds, pine, cashew, and pistachio. J. Food Quality 2017, 2017, 9038257. [CrossRef]

38. Buranasompob, A.; Tang, J.; Powers, J.R.; Reyes, J.; Clark, S.; Swanson, B.G. Lipoxygenase activity in walnuts and almonds. LWT. Food Sci. Technol. 2007, 40, 893-899.

39. Gama, T.; Wallace, H.; Trueman, S.; Hosseini-Bai, S. Quality and shelf life of tree nuts: A review. Sci. Hort. 2018, 242, 116-126. [CrossRef]

40. Yada, S.; Lapsley, K.; Huang, G. A review of composition studies of cultivated almonds: Macronutrients and micronutrients. J. Food Compos. Analysis 2011, 24, 469-480. [CrossRef]

41. Lin, J.T.; Liu, S.C.; Hu, C.C.; Shyu, Y.S.; Hsu, C.Y.; Yang, D.J. Effects of roasting temperature and duration on fatty acid composition, phenolic composition, Maillard reaction degree and antioxidant attribute of almond (Prunus dulcis) kernel. Food Chem. 2016, 190, 520-528. [CrossRef]

42. Schlörmann, W.; Birringer, M.; Böhm, V.; Löber, K.; Jahreis, G.; Lorkowski, S.; Müller, A.; Schöne, F.; Glei, M. Influence of roasting conditions on health-related compounds in different nuts. Food Chem. 2015, 180, 77-85. [CrossRef]

43. Hojjati, M.; Lipan, L.; Carbonell-Barrachina, Á.A. Effect of roasting on physicochemical properties of wild almonds (Amygdalus scoparia). J. Am. Oil Chem. Soc. 2016, 93, 1211-1220. [CrossRef]

44. Ghafoor, K.; Al-Juhaimi, F.; Geçgel, Ü.; Babiker, E.E.; Özcan, M.M. Influence of Roasting on Oil Content, Bioactive Components of Different Walnut Kernel. J. Oleo Sci. 2020, 69, 423-428. [CrossRef] [PubMed]

45. Čolić, S.; Zec, G.; Natić, M.; Fotirić-Akšić, M. Almond (Prunus dulcis) oil. In Fruit Oils: Chemistry and Functionality; Ramadan, M., Ed.; Springer: Berlin/Heidelberg, Germany, 2019; pp. 149-180.

46. Fokou, E.; Achul, M.; Kanscil, G.; Ponkal, R.; Fotso, M.; Techouanguep, F. Chemical properties of some cucurbitacease oils from Cameroon. Pak. J. Nut. 2009, 8, 1325-1334. [CrossRef]

47. Ulbricht, T.L.V.; Southgate, D.A.T. Coronary heart disease: Seven dietary factors. Lancet 1991, 338, $985-992$. [CrossRef]

48. Santos-Silva, J.; Bessa, R.J.B.; Santos-Silva, F. Effect of genotype, feeding system and slaughter weight on the quality of light lambs: II. Fatty acid composition of meat. Livest. Prod. Sci. 2002, 77, 187-194. [CrossRef]

49. Civille, G.V.; Lapsley, K.; Huang, G.; Yada, S.; Seltsam, J. Development of an almond lexicon to assess the sensory properties of almond varieties. J. Sens. Stud. 2010, 25, 146-162. [CrossRef]

50. Franklin, L.M.; Mitchell, A.E. Review of the Sensory and Chemical Characteristics of Almond (Prunus dulcis) Flavor. J. Agric. Food Chem. 2019, 67, 2743-2753. [CrossRef]

51. Erten, E.; Cadwallader, K. Identification of predominant aroma components of raw, dry roasted and oil roasted almonds. Food Chem. 2017, 217, 244-253. [CrossRef]

52. Vázquez-Araújo, L.; Verdú, A.; Navarro, P.; Martínez-Sánchez, F.; Carbonell-Barrachina, Á.A. Changes in volatile compounds and sensory quality during toasting of Spanish almonds. Int. J. Food Sci. Technol. 2009, 44, 2225-2233. [CrossRef]

53. Xiao, L.; Lee, J.; Zhang, G.; Ebeler, S.E.; Wickramasinghe, N.; Seiber, J.; Mitchell, A.E. HS-SPME GC/MS characterization of volatiles in raw and dry-roasted almonds (Prunus dulcis). Food Chem. 2014, 151, 31-39. [CrossRef] 
54. Vickers, Z.; Peck, A.; Labuza, T.; Huang, G. Impact of almond form and moisture content on texture attributes and acceptability. J. Food Sci. 2014, 79, S1399-S1406. [CrossRef] [PubMed]

55. Cheely, A.N.; Pegg, R.B.; Kerr, W.L.; Swanson, R.B.; Huang, G.; Parrish, D.R.; Kerrihard, A.L. Modeling sensory and instrumental texture changes of dry-roasted almonds under different storage conditions. LWT 2018, 91, 498-504. [CrossRef]

56. King, E.S.; Chapman, D.M.; Luo, K.; Ferris, S.; Huang, G.; Mitchell, A.E. Defining the Sensory Profiles of Raw Almond (Prunus dulcis) Varieties and the Contribution of Key Chemical Compounds and Physical Properties. J. Agric. Food Chem. 2019, 67, 3229-3241. [CrossRef]

57. Re, R.; Pellegrini, N.; Proteggente, A.; Pannala, A.; Yang, M.; Rice-Evans, C. Antioxidant activity applying an improved ABTS radical cation decolorization assay. Free Rad. Biol. Med. 1999, 26, 1231-1237. [CrossRef]

58. Siddhraju, P.; Becker, K. Antioxidant properties of various solvents extracts of total phenolic constituents from three different agroclimatic origins of drumstick tree (Moringa oleifera Lam) leaves. J. Agric. Food Chem. 2003, 51, 2144-2155. [CrossRef]

59. Salleh, W.; Ahmad, F.; Yen, K.; Sirat, H. Chemical compositions, antioxidant and antimicrobial activity of the essential oils of Piper officinarum (Piperaceae). Nat. Prod. Commun. 2003, 7, 1659-1662. [CrossRef]

60. EEC European Commision. EU Official Method (EEC Regulation 2568/91, Corresponding to AOCS Method Ch 2-91); European Commision: Brussels, Belgium, 1991.

Publisher's Note: MDPI stays neutral with regard to jurisdictional claims in published maps and institutional affiliations. 